\title{
Moscow bids farewell to the nation's dead hero
}

- Academician Andrei Sakharov is buried - A city pays its respects

\section{Moscow, Monday}

THE nation's grief has never been so allpervading and sincere as now, when Moscow bids farewell to Academician Andrei Sakharov, the "conscience of the nation". The sense of loss compares in its magnitude only to that at Yuri Gagarin's funeral.

The days that have passed since Sakharov's death on 14 December have shown graphically what profound respect he commanded among the people - this once-defamed man of harsh destiny, the father of the Soviet H-bomb, who spent years in exile under Brezhnev for advocating human rights; the man who bewildered the world with dazzling intellectual revelations and brought it the ideas of new thinking, new relations between different systems; and, finally, the first Soviet holder of the Nobel peace prize.

On 17 December, the temperature in Moscow fell to 20 degrees below zero Centigrade. People fell into long and silent lines along Komsomolsky Avenue where the coffin with Sakharov's body was placed in the Youth Centre. The traditional guard of honour over the body was absent this time: instead, taking shifts every 4 or 5 minutes, were People's Deputies, scholars, Sakharov's colleagues in research and public life, members of the Academy of Sciences of the USSR, poets, writers, representatives of numerous democratic movements and societies.

The ceremony ended at midnight instead of the scheduled 5 p.m. A simple yet moving token of the nation's tribute to the dead academician was a heap of red carnations piled up near the coffin, adorned with funeral wreaths contributed by official and unofficial organizations from all parts of the country.

Today, the ceremony has continued at FIAN, the Lebedev Physical Institute, whence a huge manifestation column set out behind the coffin with Sakharov's body, carried on people's shoulders to the Luzhniki Stadium, where the ceremony became a truly national memorial meeting.

The image of the contentious academician will persist in people's memory. A brilliant physicist-theoretician, he became an academician at 32 , the youngest in the Soviet Union. His work on the hydrogen bomb, pioneer ideas on thermo-nuclear synthesis and a number of discoveries in other fields brought him recognition as an outstanding scientist.

$\mathrm{He}$ was decorated with the Lenin Order, three Stars of the Hero of Socialist
Labour, and given the Stalin Prize - and prohibited from leaving the Soviet Union for reasons of state secrecy.

"Among our scientists, he was, as the saying goes, a transparently-honest man", wrote Nikita Khruschchev in his memoirs. "He hated to think that science might be used for the destruction of life, poisoning the atmosphere and slow killing of the people by nuclear pollution."

Yet it was Khrushchev who failed to

\section{IMAGE \\ UNAVAILABLE FOR COPYRIGHT REASONS}

Paying tribute - a long line of Muscovites queue outside the Youth Centre.

heed Sakharov's request not to resume nuclear tests in 1961. This is how Sakharov characterized the ensuing series of H-bomb test explosions: "It was terrible. I became a different man after that." He did not quit science, but concentrated on politics and free thinking, officially called dissent and equated to a crime against the state or a psychiatric disease.

It was hard to send Sakharov to a psychiatric hospital and he thus became a symbol of conscience and hope. The desperate letters imploring him for help often bore a simple address: "Academician Sakharov, Moscow". And he undertook to defend the persecuted in the press, in court rooms and in public, even when he realized that his efforts would be in vain.

The Brezhnev system took up the challenge. Without official accusation and trial, Sakharov was sent to the city of Gorky, inaccessible to foreigners for state security reasons. (The exile ended in 1986 with a telephone call from Mikhail Gorbachev.) Academicians denounced him, but he was never expelled from the academy even in the darkest days of witchhunting, much to the credit of that institution. He stayed in the Soviet Union, having retained his firm civic stand, unperturbed by any persecutions.

In his book Reflections on Progress, Peaceful Coexistence and Intellectual Freedom, published in the West in 1968, he called for the elimination of the arms race and the solution of global issues hunger, racism, disproportionate development of nations and environmental pollution. In 1975 he wrote a book On Knowledge and the World. The ideas he developed in that book are obviously parallel to those advanced and discussed in the Soviet Union now.

People's Deputy Sakharov considered perestroika to be an event of major magnitude for the Soviet Union and the entire world. He wanted this process to be more speedy and radical in this country. He perceived perestroika as a harbinger of the times when the patient Soviet people's long-cherished aspirations and hopes would finally come true.

By his nature, he could not stay aloof from what was going on in his country and abroad, and spoke at the Second Congress of People's Deputies on the day of his death. One of the leaders of the parliamentary inter-regional group, Sakharov was loyal to the end to his absolute and irreconcilable civic stand. The nation will forever remember him as a true patriot, a citizen of his country'and the world, a person with an open and generous heart and a fighter for justice and the priority of common human values.

Academician Andrei Sakharov was buried at the Vostryakovo Cemetery in Moscow on 18 December 1989.

Yuri Kanin

Moscow correspondent Novosti Press Agency

SPACE STATION

\section{A Mir $\$ 10$ million}

\section{Tokyo}

THE Soviet Union has some bargains going in slightly used space stations. But do not rush - the Japanese were there first. Last week, in one of the oddest sales of the decade, a tiny Japanese company capitalized at just $\$ 7,000$ bought the back-up Mir space station for $\$ 10$ million.

The Horie Group company has only ten employees and usually does nothing more exciting than organize seminars on space. It bought the station while it was on display at World Design Expo 1989, held in Nagoya from 15 July to 26 November. The space station had been on display earlier at exhibitions in France and Canada but there were no takers.

Horie Group says it has no immediate plans to launch the space station but it will allow Japanese companies interested in developing space technology to study it.

David Swinbanks 